\title{
Effect of the Diets Supplemented with Artichoke and Shrimp by-Products on Obese Rats
}

\author{
N.I.E. Abo Elnaga ${ }^{1}$, Mona I. Massoud ${ }^{2}$, Amal M. Abd El-Razek ${ }^{3}$,Mohamed Emad A. Nasser ${ }^{4}$ and \\ Amany R. Elgazzar ${ }^{1}$
}

\begin{abstract}
Foods supplemented with functional fiber are an effective means for prevention of diseases like obesity, cardiovascular diseases, and diabetes mellitus. The objective of this study was to estimate the dietary fiber content in artichoke stems by-product powder (ASP) and shrimp by-product powder (SBP) and evaluate the protective effect of diet supplemented with their byproducts as natural dietary fiber on weight gain, the blood picture, serum biochemical parameters and liver enzymes activities in obese rats. The results revealed that the crude fiber content was $\mathbf{2 2 . 6 8 \%}$ in the ASP and $13.65 \%$ in SBP. Total dietary fiber fractions were composed of 18.69 and 0.42\% soluble dietary fiber, 25.01 and $58.57 \%$ insoluble dietary fiber in defatted ASP and SBP, respectively. They also presented high amounts of inulin $(18.2 \mathrm{~g} / 100 \mathrm{~g}$ artichoke stem) and chitin (58.15 g/100 $\mathrm{g}$ shrimp shell). Biological impacts were done on the control group (CG) and compared with obese rat groups which were classified into seven groups; positive group (PC) and groups fed on diet supplemented with ASP and SBP at a level of 5 and $10 \%$, inulin at dose $7.7 \%$, and chitosan at dose $2.6 \%$, for 8 weeks. The results showed significant improvement and ameliorated reduction in final body weight, body weights gain (\%) and feed efficiency ratio (FER) in all the treated groups compared with the PC. Administration of $10 \%$ ASP or SBP significantly decreased body weight by 37.66 and $35.61 \%$, respectively as compared to the high fat diet (HFD) group, while the highest reduction in body weight gain and lower FER were obtained in groups fed on chitosan. Feeding obese rats on diet containing ASP and SBP led to a reduction in the total cholesterol, triglycerides, and low-density lipoprotein cholesterol concentration, decreased in blood glucose level and improved serum liver enzymes activity and antioxidant enzyme activity as compared to the positive group. ASP as a source of inulin and SBP as a source of chitin can be used in the nutraceutical formulation of functional food products and a good source of natural dietary fiber to enhance the nutritional quality for prevention of diseases like obesity, and its associated health risks.
\end{abstract}

DOI: 10.21608/asejaiqjsae.2021.169609

${ }^{1}$ Home Economics Dept Agric., Fac. of Agric. El-Shatby,

Alexandria Univ., Alexandria, Egypt.

${ }^{2}$ Sugar Crops Research Institute, Agric. Research Center,

El-Sabahia, Egypt.

${ }^{3}$ Food Science \& Technology Dept., Fac. of Agric. El-Shatby,21545,

Alexandria Univ., Alexandria, Egypt

${ }^{4}$ Dept.of animal and Fish Production, Fac. of Agric. El-Shatby,

Alexandria University, Alexandria, Egypt.

Received April 04, 2021, Accepted May 05, 2021.
Keywords: Functional fiber, natural dietary fiber, inulin, chitin and nutraceutical.

\section{INTRODUCTION}

There is a worldwide interest with natural dietary fiber that possess many beneficial nutritive and physiological effects in humans such as enhancement of immune system, improvement of digestive functions and reduces risk for developing some diseases like obesity, heart disease, diabetes, dyslipidemia, hypertension and osteoarthritis (Fernstrand et al., 2017 and Siracusa et al., 2019).

A promising source of functional compounds is food by-products because of their nutritional and rheological properties where they are composed of protein, fats, nondigestible carbohydrate, bioactive compounds, and phytochemicals. Vegetable-by- product such as artichoke by-product is a source of inulin and rich source of bioactive compounds which protect against heart disease and cancer (Fratianni et al., 2007). Inulin known as fructans, is a polysaccharide, consisting of polymer of fructose with $\beta$ (2-1) glycosidic linkage. Inulin is a prebiotic non-digestible dietary fiber that beneficially affects the host by selectively stimulating the growth of beneficial bifidobacteria, production of short chain fatty acids (SCFAs), calcium absorption, decrease in body weight gain and thus improves immune health (Franco-Robles and López, 2015 and Mohanty et al., 2018).

Seafood wastes such as shrimp shell is the most abundant source of chitin as a natural biopolymer after cellulose as well as, it contains $30-40 \%$ protein, $30-50 \%$ calcium carbonate and calcium phosphate (No and Meyers, 1995). Chitin is a linear polymer of anhydro Nacetyl glucosamine, and can be converted into chitosan, chito- oligosaccharides and glucosamine augments its biological properties and applications in various industries such pharmaceuticals, and food industries 
(Muzzarelli, 1985 and Yadav et al., 2019). Approximately 2000 tons of chitosan is produced annually, whose main source of extraction is from shrimp and crab shell residues ( GIA ,2005- Muñoz et al., 2018).

The amount of stem resulting from artichoke processing is about $35-30 \%$ of the total raw material and shrimp industries caused approximately $60-70 \%$ of shrimp shell that usually consist of head, skin, and tail. These wastes cause many environmental problems and becoming a source of pollution (Lertsutthiwong et al., 2002). On the other hand, these wastes which are rich in dietary fiber are soluble and insoluble fibers, and are reported to improve serum lipid profile (Larrosa et al., 2021), lowers blood pressure, (Soliman, 2019) improves blood glucose, (Hopping et al., 2010) promotes of bone health (Dai et al., 2018), appears to enhance of disease resistance through immune function (Sharma et al., 2019 and Rawi et al., 2020), energy and improvement of digestive functions (Grundy et al.,2016).

The recommended daily dietary fiber intake is 28 $\mathrm{g} /$ day for adult women and $36 \mathrm{~g} /$ day for adult men (USDA, 2005, Anderson and Hanna, 1999).

Dietary fiber is a complex compound that includes non-fermentable and fermentable compounds. The fermentable compounds are fermented to SCFAs produced include butyrate, acetate and propionate which lead to mediate many potential physiological effects such as improved glycemic and insulinaemic responses, improved blood lipid profile, increased satiety and reduced energy intake, increased micronutrient absorption and decrease in $\mathrm{pH}$ by the microflora in the large intestine. The increased prevalence of obesity and its associated health risks justify the need to discover effective dietary treatments to weight loss. Dietary fiber from food by-product such as chitin, and inulin to increase satiety and lower energy then weight reduction, requires confirmation in further studies (Mohanty et al., 2018).

Therefore, the aim of this study was to determine the dietary fiber of artichoke and shrimp by-products and to investigate the effect of the diet supplemented with these by-products on weight loss and biochemical measurements in obese rats.

\section{MATERIALS AND METHODS}

\section{Artichoke stems by-product powder (ASP)}

The Globe artichoke (Cynara scolymus L.) stem byproduct samples were collected from local market of Alexandria, Egypt. The stem by-product was peeled, sliced and soaked in $1 \%$ citric acid solution then dried in a cabinet drier (Universal hot air oven, Tradevel Scientific Industries) at $40^{\circ} \mathrm{C}$ for $48 \mathrm{~h}$., grounded to pass through 60 mesh sieve and stored at $20^{\circ} \mathrm{C}$ until used for analysis.

\section{Shrimp by-product powder (SBP)}

Fresh squilla (Oratosquilla massavensis) by-product samples were collected from the commercial fish ring at El-Anfoshy and El-Midan local market, Alexandria, Egypt. Shrimp by-product was washed, dried overnight at $40^{\circ} \mathrm{C}$ using the above-mentioned electric oven, then grounded and stored as mentioned above.

Chemical analysis: Moisture content was determined of ASP and SBP samples by drying at $110^{\circ} \mathrm{C}$ to a constant weight according to A.O.A.C. method No.945.43 (2000). Crude fiber content was determined according to A.O.A.C. method No.935.53 (2000) method using Fiber analyzer (Ankom 200. Model No. A220, USA). Dietary fiber fractions including neutral detergent fiber (NDF), acid detergent fiber (ADF), and acid detergent lignin (ADL) were analyzed after extraction of oil from samples as mentioned in the methods of Goering \& Van Soest (1970). Hemicelluloses and cellulose were calculated as follows: Hemicelluloses $(\%)=\%$ NDF - $\%$ ADF, Cellulose $(\%)=\%$ ADF - \%ADL. Soluble dietary fibers (SDF), insoluble dietary fibers (IDF) and total dietary fibers (TDF), were determined as mentioned in A.O.A.C. (2000). Inulin was extracted from ASP sample according to the method of Van Waes et al. (1998) and was determined by fructose-resorcinol-hydrochloric acid assay using fructose as sugar standard (Sadasivam and Manickam, 1992). Chitin was extracted and determined in SBP samples according to the procedure of Abouzeed et al. (2015). The chemical analysis of samples was run in triplicates.

\section{Animals experiment design}

Forty-eight healthy Wistar rats, (weighting from 73 to $86 \mathrm{~g}$ ), were obtained from the animal house of Home Economics Laboratory, Faculty of Agriculture, Alexandria University, Egypt. Rats were housed under laboratory conditions of temperature at $23 \pm 3^{\circ} \mathrm{C}$ with a $12 \mathrm{~h}$ light-dark cycle and were given standard diet and access to distilled water ad libitum. The protocol of the National Institutes of Health (NIH) to the guidelines was followed (Collins, 2008). After seven days, the rats were randomly divided into two groups; control diet group as negative control $(\mathrm{CG}, \mathrm{n}=6)$ fed according to Lane-Peter and Person (1971) and high-fat diet group $(n=42)$ which were fed a high-fat diet (HFD) according to BleCastillo et al. (2012) for two months to induce obesity. After confirming that the HFD rats were obese the rats were subdivided into seven group (6 rats for each group), HFD positive control (PC) group, and six groups, as follows: Group I and 2: HFD group fed on diet $\mathrm{A}$ and $\mathrm{B}$ containing $5 \%$, and $10 \%$ ASP, respectively. Group 3: HFD group fed on diet C 
containing inulin at dosage $7.7 \mathrm{~g} / \mathrm{kg}$ deit. Group 4 and 5: HFD group fed on diet D and E containing 5\% and $10 \%$ SBP, respectively. Group 6: HFD group fed on diet F containing chitosan at dosage $2.6 \mathrm{~g} / \mathrm{kg}$ deit. The quantities of diet prepared every day, and the feeding was carried out for 8 weeks as reported by Reeves et al. (1993).

\section{Weight gain and food intake}

The feed intake of the rats was recorded daily, and body weights were monitored each week throughout the experiment. Average food intake (AFI), average weight gains (AWG) and the feed efficiency coefficient (FEC) were evaluated according to the method of Chapman et al. (1959).

\section{Hematological parameters and biochemical estimations}

At the end of the experiment period (two month), rats were sacrificed after overnight fasting under ethesthesia. Blood samples were collected from the territorial venous plexus and immediately transferred into heparinized micro tubes for hematological assays and non-heparinized tubes for biochemical analysis. Hematological assays included white blood cell (WBC), hemoglobin $(\mathrm{Hb})$, red blood cell (RBC), hematocrit (HCT), mean globular volume (MGV), and mean corpuscular hemoglobin $(\mathrm{MCH})$, mean corpuscular hemoglobin concentration (MCHC) and platelets. For serum biochemical investigations, blood samples were centrifuged at $900 \mathrm{xg}$ for $20 \mathrm{~min}$. Serum total lipids (TL) was determined according to Zollner and Kirsch (1962). Triglyceride (TG) was done as described by Fossati and Prencipe (1982) method and total cholesterol (TC) by the method of Tietz (1976). High density lipoprotein cholesterol (HDL-C) was determined according to Wieland and Seidel (1983) method. The low-density lipoprotein cholesterol (LDL-C) and very low-density lipoprotein cholesterol (VLDL-C) levels were calculated using the Friedewald formula (Friedewald et al., 1972 and Warnick et al., 1990). Serum glucose measured by enzymatic GOD/POD kits according to Trinder, 1969. Total protein, albumin, globulin, creatinine, total bilirubin and blood urea nitrogen were determined as described by Lowry et al. (1951), Doumas et al. (1971), Henry et al. (1974), Young (2001) and Vassault, et al. (1986), respectively. Serum alanine aminotransferase (ALT), aspartate aminotransferase (AST) and alkaline phosphatase (ALP) activities were assayed using the Bergmeyer et al. (1978) method. Serum acid phosphatase (ACP) activity was measured according to the method of Kind and King (1954). the internal organs namely liver, kidney, heart, brain and lung were excised and weighed from each group.

Estimation of antioxidant enzyme activities: Catalase activity (CAT) was determined according to the method of Sinha (1972), glutathione peroxidase (GSH-Px) by Paglia and Valentaine (1967), and the hepatic superoxide dismutase (SOD) activity was measured according to the method of Kakkar et al. (1984).

\section{Statistical analysis}

All statistics were performed with commercially available software (SPSS ver. 22.0 for Windows, 2010; SPSS, Chicago, IL) Continuous variables were given as means \pm standard Deviation (SD). Statistical analysis of variance was performed using the one-way ANOVA test using Duncan's multiple range test and followed by the least significant difference (LSD) test to locate significantly between all treatments. Differences were considered significant at $\mathrm{p}<0.05$.

\section{RESULTS AND DISCUSSION}

\section{Crude and dietary fiber fractions of (ASP) and (SBP)}

As shown in Table (1), the value of crude fiber were $22.68 \%$ and $13.65 \%$ (dry matter) in the ASP and SBP, respectively. The results of crude fiber value of ASP were in agreement and very close with those mentioned by Salman et al. (2014) and Attia et al. (2016) who reported that the crude fiber content in artichoke floral stem by-product was ( $24.22-24.35 \%$ on dry basis) and higher than those reported by Eman et al. (2018) who recorded that the crude fiber content of artichoke floral stem by- product was $14.50 \%$ but lower than those found by Claus et al. (2015) (44.23\% on dry basis). Defatted samples contained high level of total dietary fiber. Defatted SBP had total dietary fiber (TDF) $58.99 \%$ which majority was insoluble form, while defatted ASP contains $43.70 \%$ TDF. ASP had a better fiber quality than those found in SBP because of ASP had high amounts of soluble dietary fiber (SDF) contents and the insoluble/ soluble dietary fiber (IDF/SDF) ratio (1.34), which was the near-perfect proportion. A higher soluble/insoluble fiber ratio of vegetables possess is considered as an indicator of fiber quality than other sources (Saura-Calixto et al., 2000). A good balance in SDF and IDF is considered important for the nutritional effects and functionality of fiber in the human diet (Vergara-Valencia et al., 2007). 
Table 1. Crude and dietary fiber fractions of (ASP) and (SBP) on dry weight basis.

\begin{tabular}{lll}
\hline Component (\%) & \multicolumn{1}{c}{ ASP } & \multicolumn{1}{c}{ SBP } \\
\hline Crude fiber & $22.68 \pm 0.60$ & $13.65 \pm 0.42$ \\
Dietary fiber (DF) & & \\
Insoluble DF & $25.01 \pm 0.85$ & $58.57 \pm 0.57$ \\
Soluble DF & $18.69 \pm 0.71$ & $0.42 \pm 0.07$ \\
Total DF & $43.7 \pm 1.13$ & $58.99 \pm 1.70$ \\
IDF/SDF & $1.34 \pm 0.11$ & $139.45 \pm 1.56$ \\
Neutral detergent fiber (NDF) & $24.91 \pm 1.67$ & $16.3 \pm 0.02$ \\
Acid detergent fiber (ADF) & $22.68 \pm 0.73$ & $13.57 \pm 0.44$ \\
Acid detergent lignin (ADL) & $18.69 \pm 1.24$ & $0.68 \pm 0.01$ \\
Hemicellulose & $2.23 \pm 0.94$ & $2.73 \pm 0.42$ \\
Cellulose & $3.99 \pm 0.51$ & $12.89 \pm 0.45$ \\
Inulin & $8.2 \pm 0.07$ & ----- \\
Chitin & ------ & $42.27 \pm 1.31$ \\
\hline
\end{tabular}

Results are expressed as mean $\pm \mathrm{SD}$

However, the soluble dietary fibers increase the viscosity of the digesta and increased viscosity in the small intestine might slow gut transit time due to suppressed intestinal contractions (Cherbut et al., 1990) which in turn leads to less mixing of dietary components with endogenous digestive enzymes (Johnston et al., 2003).

The results in Table (1) also was indicated that there were a difference between neutral detergent fiber (NDF) which represents hemicellulose, cellulose and lignin along with acid detergent fiber (ADF) and acid detergent lignin (ADL) contents of the two by-products. The yields of the NDF, ADF and ADL of artichoke stem by-product (ASP) were higher than that in shrimp by-product (SBP). On the other hand, cellulose of shrimp by-product was higher than that of artichoke stem by-products. Similar observations have also been reported by earlier researchers. Meneses et al. (2007) mentioned that the NDF, ADF and ADL content of artichoke by-product were $42.9,30.3 \%$ and 10.3 , respectively. Also, the data in Table (1) showed that the percentages of inulin were $43.87 \%$ and $18.76 \%$ out of the SDF and TDF of the ASP, respectively. Inulin is the most important nutritional fraction in tubers and has a dietary health benefits which it forms a perfect nutrient medium for bifidobacteria cells in an alimentary tract (Shoaib et al., 2016) and reduces triglycerides, LDLcholesterol, blood glucose, with improves calcium absorption and inhibits the growth of various kinds of cancer (Whisner and Castillo, 2018). It could be seen from the same Table that, the chitin was found in high quantity and valued $71.66 \%$ out of the TDF in SBP. On the other hand, it was higher than that reported by Tokatlı and Demirdoven (2017) who reported that the chitin yield was $10.13 \%$ of the dry weight of the shrimp shell.

Effect of artichoke stem by-product (ASP) and shrimp by-product (SBP) administration on weight gain and feed intake in obese rats

From the present results in Table (2), the average initial weight of different HFD groups of animals $(249.33 \pm 8.14-252.25 \pm 0.99 \mathrm{~g})$ was significantly greater than that in the normal control group (149.00 \pm $1.00 \mathrm{~g}$ ), This increment in the body weight was related to increase fat intake by rats which can promote increased visceral fat deposition leading to obesity as it is the most energy-dense macronutrient (Allioua et al., 2015). At the end of 60 days fed, the data presented revealed that there were significant reduction in body weight and body weight gain (\%) of all HFD group fed different byproduct samples when compared to the positive control group. Administration of $10 \%$ ASP or SBP significantly reduced body weight by 37.66 and $35.61 \%$, respectively as compared to the positive control group. Administration of chitosan caused a significant reduction body weight by $6.79 \%$ compared to the negative group and by $42.01 \%$ compared to the positive group as shown in Table (2), while rats fed $7.7 \%$ inulin showed significant reduction in body weight by $36.21 \%$ compared with that of the positive control and insignificant change when compared with that of the control diet. 
Table 2. Changes in body weight gain, food intake and feed efficiency ratio in obese rats fed with artichoke stem by product (ASP), shrimp by-product (SBP), inulin and chitosan and normal diet.

\begin{tabular}{lccccc}
\hline Parameters & $\begin{array}{c}\text { Initial body } \\
\text { weight }(\mathbf{g})\end{array}$ & $\begin{array}{c}\text { Final body } \\
\text { weight }(\mathbf{g})\end{array}$ & $\begin{array}{c}\text { Body weight } \\
\text { gain }(\%)\end{array}$ & $\begin{array}{c}\text { daily Food } \\
\text { intake (g/day) }\end{array}$ & $\begin{array}{c}\text { Feed efficiency } \\
\text { ratio (FER) }\end{array}$ \\
\hline CG (Control diet) & $149.00 \pm 1.00^{\mathrm{a}}$ & $171.67 \pm 2.89^{\mathrm{b}}$ & 15.21 & $21.83 \pm 0.35^{\mathrm{bc}}$ & $0.03 \pm 0.001^{\mathrm{d}}$ \\
PC (HFD diet) & $252.25 \pm 0.99^{\mathrm{b}}$ & $275.91 \pm 3.61^{\mathrm{d}}$ & 9.38 & $20.56 \pm 0.51^{\mathrm{a}}$ & $0.18 \pm 0.004^{\mathrm{e}}$ \\
A (ASP 5\%) & $249.67 \pm 0.58^{\mathrm{b}}$ & $199.00 \pm 1.00^{\mathrm{c}}$ & -20.29 & $22.50 \pm 0.29^{\mathrm{c}}$ & $-0.06 \pm 0.001^{\mathrm{c}}$ \\
B (ASP 10\%) & $249.33 \pm 8.14^{\mathrm{b}}$ & $172.00 \pm 3.00^{\mathrm{b}}$ & -31.02 & $22.58 \pm 0.16^{\mathrm{bc}}$ & $-0.10 \pm 0.001^{\mathrm{a}}$ \\
C (7.7\% inulin) & $254.33 \pm 4.73^{\mathrm{b}}$ & $176.00 \pm 6.00^{\mathrm{b}}$ & -30.79 & $21.61 \pm 0.25^{\mathrm{b}}$ & $-0.11 \pm 0.001^{\mathrm{a}}$ \\
D (SBP 5\%) & $253.00 \pm 5.00^{\mathrm{b}}$ & $184.33 \pm 3.21^{\mathrm{c}}$ & -27.14 & $22.61 \pm 0.22^{\mathrm{c}}$ & $-0.08 \pm 0.001^{\mathrm{b}}$ \\
E (SBP 10\%) & $254.00 \pm 3.46^{\mathrm{b}}$ & $177.67 \pm 2.52^{\mathrm{b}}$ & -30.05 & $22.32 \pm 0.28^{\mathrm{bc}}$ & $-0.08 \pm 0.001^{\mathrm{b}}$ \\
F (2.6\% chitosan) & $250.00 \pm 5.29^{\mathrm{b}}$ & $160.00 \pm 5.29^{\mathrm{a}}$ & -36.00 & $24.33 \pm 0.33^{\mathrm{d}}$ & $-0.11 \pm 0.001^{\mathrm{a}}$ \\
\hline
\end{tabular}

Results are expressed as mean $\pm \mathrm{SD}$; Means with different superscript letters in the same column imply significant differences at $\mathrm{P} \leq 0.05$.

From the reduction in body weight gain results, it could be arranged the groups fed with by product, in a descending order as follows: Group F (-42.01\%), followed by group B $(-37.66 \%)$, group C $(-36.21 \%)$, group E (-35.61\%), then group D (-33.19\%), finally group A (27.87\%) when compared with the positive control group. This was due to characteristics, and quantity of the fiber, which may have effects. on body weight gain (Zhong et al., 2007). The treatment at doses $200-400 \mathrm{mg} / \mathrm{kg} / \mathrm{bw}$ artichoke extracts significantly decreased in body weight gain compared with HFD groups (Küçükgergin et al., 2010).

After 60 days fed control diet for group 1 and HFD for the other groups ASP or SBP treated group significantly $(\mathrm{P} \leq 0.05)$ increased feed intake as compared to the positive control group but non significant $(\mathrm{P} \leq 0.05)$ as compared to the negative control group. The results showed that HFD group gave the highest FER and while the group either fed 10\% ASP (B) and group fed on inulin (C) or group fed on chitosan
(F) had lower FER than the other groups. Group D and E which fed on SBP gave the same FER (-0.08) as shown in Table (2). Similar result with those mentioned by Khambualai et al. (2008) and Ogungbemi et al. (2020) who stated that the body weight of the rats fed chitosan improved feed intake resulting in increased feed efficiency than those fed HFD diet. Addition of ASP as a source of inulin and SBP as a source of chitin in the diet appears protect against the promotion of energy intake, body weight gain. It could that may be fat mass development induced by a high-fat diet by increasing the fermented and the remainder passes through the colon as an insoluble fiber (Soliman, 2019).

Effect of artichoke stem (ASP) and shrimp byproducts (SBP) administration on relative organ weights of rat

The data in Table (3) showed that there were insignificant changes of liver, kidney and heart relative weights in all groups when compared with the negative group.

Table 3. Changes in the relative organ weights of obese rats fed on artichoke stem (ASP), shrimp by-product (SBP), inulin and chitosan and normal diet.

\begin{tabular}{|c|c|c|c|c|c|}
\hline $\begin{array}{l}\text { Organs } \\
\text { Experimental groups }\end{array}$ & Liver & Kidney & Heart & Brain & Lung \\
\hline CG (Control diet) & $2.87 \pm 0.09^{\mathrm{a}}$ & $0.87 \pm 0.02^{\mathrm{ab}}$ & $0.34 \pm 0.02^{\mathrm{ab}}$ & $0.77 \pm 0.03^{\mathrm{cd}}$ & $0.76 \pm 0.41^{\mathrm{bc}}$ \\
\hline PC (H F D diet) & $3.02 \pm 0.08^{\mathrm{a}}$ & $1.01 \pm 0.03^{b}$ & $0.35 \pm 0.03^{b}$ & $0.80 \pm 0.03^{\mathrm{d}}$ & $0.80 \pm 0.48^{c}$ \\
\hline A (ASP 5\%) & $2.62 \pm 0.03^{\mathrm{a}}$ & $0.80 \pm 0.01^{\mathrm{a}}$ & $0.28 \pm 0.04^{\mathrm{a}}$ & $0.75 \pm 0.03 \mathrm{bcd}$ & $0.67 \pm 0.42^{a b}$ \\
\hline B (ASP 10\%) & $2.86 \pm 0.05^{\mathrm{a}}$ & $0.84 \pm 0.01 \mathrm{ab}$ & $0.34 \pm 0.06^{\mathrm{ab}}$ & $0.77 \pm 0.03^{\mathrm{cd}}$ & $0.62 \pm 0.38^{a}$ \\
\hline $\mathrm{C}(7.7 \%$ inulin $)$ & $2.92 \pm 0.03^{\mathrm{a}}$ & $0.86 \pm 0.01^{\mathrm{ab}}$ & $0.32 \pm 0.04^{\mathrm{ab}}$ & $0.72 \pm 0.04 \mathrm{abc}$ & $0.72 \pm 0.30^{b}$ \\
\hline $\mathrm{D}(\mathrm{SBP} 5 \%)$ & $2.79 \pm 0.03^{\mathrm{a}}$ & $0.84 \pm 0.01^{\mathrm{ab}}$ & $0.31 \pm 0.03^{\mathrm{ab}}$ & $0.69 \pm 0.03$ ab & $0.69 \pm 0.38 \mathrm{ab}$ \\
\hline E (SBP 10\%) & $2.57 \pm 0.05^{\mathrm{a}}$ & $0.82 \pm 0.01^{\mathrm{a}}$ & $0.34 \pm 0.06^{\mathrm{ab}}$ & $0.67 \pm 0.05^{\mathrm{a}}$ & $0.73 \pm 0.26^{\mathrm{bc}}$ \\
\hline $\mathrm{F}(2.6 \%$ chitosan $)$ & $2.77 \pm 0.08^{\mathrm{a}}$ & $0.84 \pm 0.01 \mathrm{ab}$ & $0.33 \pm 0.02$ ab & $0.72 \pm 0.07 \mathrm{abc}$ & $0.68 \pm 0.30^{\mathrm{ab}}$ \\
\hline
\end{tabular}

Results are expressed as mean $\pm \mathrm{SD}$; Means with different superscript letters in the same column imply significant differences at $\mathrm{P} \leq 0.05$. 
Rats fed with SBP were showed a significantly lower of brain relative weight compared with the normal or HFD diet groups. On the other hand, rats in the $\mathrm{C}$ and $\mathrm{F}$ groups had significantly lower brain relative weights when compared to the positive control. All treated groups showed significant decreases in lung relative weights except the E group (SBP 10\%) when compared with the positive control. Chitosan oligosaccharide prevented increases in organ weight in mice fed on a high fat diet (Sumiyoshi et al., 2006). Huang et al. (2015) showed that the liver index of the high fat group significantly differed from those of chitosan groups.

Blood picture examination of obese rats fed on artichoke stem by product (ASP) and shrimp byproduct (SBP)

As shown in Table (4), there were insignificant changes observed in most parameters examined after 8 weeks such as hemoglobin (Hb), red blood cells (RBC), mean corpuscular hemoglobin $(\mathrm{MCH})$, mean cell volume (MCV), mean corpuscular hemoglobin concentration (MCHC), red cell distribution width (RDW-CV) red cell distribution width standard deviation (RDW-SD), and platelets count (PLT). However, a significant reduction was noted after 8 weeks for all treated groups in the white blood cells (WBC) and hematocrit (HCT) when compared to the positive group. Administration of artichoke leaves extract $(200-400 \mathrm{mg} / \mathrm{kg}$ ) for one-month rats increased the levels of $\mathrm{WBC}, \mathrm{RBC}, \mathrm{Hb}, \mathrm{MCV}, \mathrm{MCH}$, and platelets to near normal values $(p \leq 0.001)$ in alloxan induced diabetic obesity rats (Salem et al., 2019).

Serum lipid profile of obese rats fed on artichoke stem by-product (ASP) and shrimp by-product (SBP)

The data recorded in Table (5) showed that there were significant increment in serum levels of TC, TG, and LDL-C of the positive control group by, 10.26, 12.09 , and $45.23 \%$, respectively when compared to the control negative group. Moreover, there were significant decrement in serum levels of HDL-C of the positive control group 54.97\% compared to the control negative group. It is clear from Table (5) that groups fed with ASP and SBP showed improvement with significant reduction in lipid profile levels when compared to the positive group.

Meanwhile, there were insignificant changes in serum TC, TG, TL, HDL-C, LDL- C, ClLDL, LDLLHDL when compared to the group fed normal diet. The highest reduction in TC was obtained in group B (13.18\%), followed by group A (12\%) then group E $(11.24 \%)$. Moreover, there were decrement in serum levels of TG level 14.53, 11.15, 11.86, 12.58, 10.52 and $12.18 \%$ for group A, B, C, D, E and F, respectively when compared to the control positive group. The rats fed on SBP showed no significant increment in serum HDL-C compared to the group of rats given ASP. Conversely, there were significant increases in serum HDL-C by $115.12 \%$ in each of rats given $5 \%$ and $10 \%$ SBP when compared to the positive group. Serum LDL-C showed a significant decrement by $34.44 \%$ and 32.68 in rats fed on $10 \%$ ASP and SBP, respectively when compared to the control positive group. Inulin at dosage $7.7 \mathrm{~g} / \mathrm{kg}$ bw and chitosan at dosage $2.6 \mathrm{~g} / \mathrm{kg}$ bw were significantly reduced in LDL-C level by 29.57 and $29.97 \%$, respectively as compared to positive group. These results are in agreement with those obtained byDelzenne and Kok (1999) and Causey et al. (2000). According to Gebhardt (1998), administration of Cynara scolymus leaves extracts for two months showed ethanol extract (EEA) from leaves of $C$. scolymus inhibited lipase activity in the plasma in HFD groups, which made a decrease in serum TC, LDL-C, and TG levels as well as a significant reduction in the calculated atherogenic index (AI). Bonsu and Johnson (2012) reported that there was no significant change in lipid profile in rats given $10 \mathrm{~g} /$ day inulin in individuals diagnosed with type 2 diabetes. The results of chitosan agreed with that study of Jiang et al (2019) who reported that chitosan consumption can improve lipid profiles of coronary heart disease (CHD) patients. Chitosan and artichoke leaf extracts had significant therapeutic potential in hypercholesterolemia, cardio protective effects and exerts the amelioration of the imbalance of circulated cholesterol and lipoprotein levels in HF diet-fed rats (Küçükgergin et al., 2010 and Chiu et al., 2020).

Effect of administration of artichoke stem byproduct (ASP) and shrimp by- product (SBP) on serum biochemical parameters liver and antioxidant enzymes and kidney function of obese rat

\section{Some biochemical parameters}

As shown in Table (6) the results revealed that administration of ASP $5 \%$, ASP 10\%, inulin, SBP 5\%, SBP $10 \%$, and chitosan to fed obese rats significantly reduced and improvement in blood glucose levels, total protein, albumin and globulin compared to the positive group after 8 weeks. It can be seen that the glucose levels decreased by $9.87,8.73,10.19,7.42$, and $9.46 \%$ in for group A, B, C, D, E and F, respectively as compared to the glucose level of the positive group. While there was no significant change in values of total protein, albumin and globulin in serum rats as compared to the negative control group (Table 6). 
Table 4. Change in blood picture of control rats and obese rats fed with artichoke by product (ASP), shrimp by-product (SBP), inulin and chitosan for 8 weeks.

\begin{tabular}{|c|c|c|c|c|c|c|c|c|}
\hline Parameters & $\begin{array}{c}\text { CG } \\
\text { (Control diet) }\end{array}$ & $\begin{array}{c}\text { PC } \\
\text { (HFD diet) }\end{array}$ & $\begin{array}{c}\text { A } \\
(\text { ASP 5\%) }\end{array}$ & $\begin{array}{c}\text { B } \\
(\operatorname{ASP} 10 \%)\end{array}$ & $\begin{array}{c}\mathrm{C} \\
\text { (7.7\% inulin) }\end{array}$ & $\begin{array}{c}\text { D } \\
(\text { SBP 5\%) }\end{array}$ & $\begin{array}{c}\text { E } \\
(\text { SBP 10\%) }\end{array}$ & $\begin{array}{c}\text { F } \\
(2.6 \% \text { chitosan })\end{array}$ \\
\hline WBCS & $9.5 \pm 0.75^{\mathrm{a}}$ & $11.2 \pm 0.69^{b}$ & $9.5 \pm 0.32^{\mathrm{a}}$ & $9.3 \pm 0.40^{\mathrm{a}}$ & $9.6 \pm 0.19^{\mathrm{a}}$ & $9.6 \pm 0.24^{\mathrm{a}}$ & $9.3 \pm 0.68^{\mathrm{a}}$ & $9.6 \pm 0.29^{\mathrm{a}}$ \\
\hline $\mathrm{Hb}$ & $15.0 \pm 0.34^{\mathrm{a}}$ & $14.7 \pm 0.30^{\mathrm{a}}$ & $15.2 \pm 0.59^{\mathrm{a}}$ & $15.3 \pm 0.42^{\mathrm{a}}$ & $15.2 \pm 0.70^{\mathrm{a}}$ & $15.1 \pm 0.43^{a}$ & $15.2 \pm 0.51^{\mathrm{a}}$ & $15.3 \pm 0.38^{a}$ \\
\hline $\mathrm{RBC}$ & $7.5 \pm 0.36^{\mathrm{a}}$ & $6.4 \pm 0.87^{\mathrm{a}}$ & $7.0 \pm 0.33^{\mathrm{a}}$ & $7.19 \pm 0.32^{a}$ & $7.38 \pm 0.34^{\mathrm{a}}$ & $7.26 \pm 0.59^{\mathrm{a}}$ & $7.12 \pm 0.48^{\mathrm{a}}$ & $7.35 \pm 0.41^{\mathrm{a}}$ \\
\hline HCT & $32.86 \pm 1.34^{\mathrm{a}}$ & $39.6 \pm 1.58^{b}$ & $33.4 \pm 1.78^{\mathrm{a}}$ & $35.0 \pm 1.82^{\mathrm{a}}$ & $35.1 \pm 2.95^{\mathrm{a}}$ & $36.0 \pm 1.69^{\mathrm{a}}$ & $37.0 \pm 3.69^{\mathrm{a}}$ & $33.2 \pm 1.43^{\mathrm{a}}$ \\
\hline $\mathrm{MCV}$ & $52.0 \pm 3.71^{\mathrm{a}}$ & $56.5 \pm 2.17^{\mathrm{a}}$ & $52.3 \pm 0.75^{\mathrm{a}}$ & $53.7 \pm 1.13^{\mathrm{a}}$ & $55.2 \pm 2.25^{\mathrm{a}}$ & $54.7 \pm 1.73^{\mathrm{a}}$ & $52.5 \pm 1.41^{\mathrm{a}}$ & $53.6 \pm 1.00^{\mathrm{a}}$ \\
\hline $\mathrm{MCH}$ & $21.8 \pm 1.25^{\mathrm{a}}$ & $21.9 \pm 0.82^{\text {a }}$ & $21.5 \pm 1.13^{\mathrm{a}}$ & $22.1 \pm 1.21^{\mathrm{a}}$ & $22.0 \pm 1.32^{\mathrm{a}}$ & $21.3 \pm 1.03^{\mathrm{a}}$ & $21.5 \pm 1.04^{\mathrm{a}}$ & $21.2 \pm 1.28^{\mathrm{a}}$ \\
\hline $\mathrm{MCHC}$ & $31.9 \pm 14.07^{\mathrm{a}}$ & $38.9 \pm 0.57$ a & $39.4 \pm 1.48^{\mathrm{a}}$ & $39.9 \pm 1.38^{\mathrm{a}}$ & $37.9 \pm 3.19^{\mathrm{a}}$ & $38.8 \pm 1.39^{\mathrm{a}}$ & $40.5 \pm 1.01^{\mathrm{a}}$ & $38.5 \pm 2.43 \mathrm{a}$ \\
\hline RDW-CV & $14.7 \pm 1.47^{\mathrm{a}}$ & $15.0 \pm 0.29^{\mathrm{a}}$ & $13.6 \pm 0.11^{a}$ & $14.0 \pm 0.57$ a & $14.9 \pm 1.01^{\mathrm{a}}$ & $14.7 \pm 0.52^{\mathrm{a}}$ & $14.4 \pm 0.59^{\mathrm{a}}$ & $14.8 \pm 0.66 \mathrm{a}$ \\
\hline RDW-SD & $29.7 \pm 2.14^{\mathrm{a}}$ & $28.8 \pm 2.68^{\mathrm{a}}$ & $29.00 \pm 0.49^{\mathrm{a}}$ & $28.9 \pm 0.56^{\mathrm{a}}$ & $29.3 \pm 0.44^{\mathrm{a}}$ & $29.1 \pm 0.66^{\mathrm{a}}$ & $28.9 \pm 0.19^{\mathrm{a}}$ & $28.9 \pm 0.50 \mathrm{a}$ \\
\hline PLT & $605.0 \pm 43.0^{\mathrm{a}}$ & $573.0 \pm 7.97^{\mathrm{a}}$ & $612.2 \pm 31.1^{\mathrm{a}}$ & $608.0 \pm 58.7^{\mathrm{a}}$ & $601.8 \pm 52.4^{\mathrm{a}}$ & $603.4 \pm 36.9^{a}$ & $603.2 \pm 54.6^{\mathrm{a}}$ & $602.4 \pm 21.6 \mathrm{a}$ \\
\hline
\end{tabular}

WBC: white blood cell, Hb: hemoglobin, RBC: red blood cell, HCT: hematocrit, MCV: mean corpuscular volume, MCH :mean cell hemoglobin, MCHC: mean cell hemoglobin concentration, RDW$\mathrm{CV}$ : red cell distribution width, RDW-SD: red cell distribution width standard deviation and PLT: platelets count. Results are expressed as mean \pm SD Means with different letters in the same row imply significant. differences at $\mathrm{P} \leq 0.05$.

Table 5. Effect of administration of artichoke by product (ASP), shrimp by-product (SBP), inulin and chitosan on serum lipid profile in obese rats

\begin{tabular}{|c|c|c|c|c|c|c|c|c|}
\hline Parameters & $\begin{array}{c}\text { CG } \\
\text { Control diet }\end{array}$ & $\begin{array}{c}\text { PC } \\
\text { (HFD diet) }\end{array}$ & $\begin{array}{c}\text { A } \\
(\text { ASP 5\%) }\end{array}$ & $\begin{array}{c}\text { B } \\
(\operatorname{ASP} 10 \%)\end{array}$ & $\begin{array}{c}\text { C } \\
\text { (7.7\% inulin) }\end{array}$ & $\begin{array}{c}\text { D } \\
(\text { SBP 5\%) }\end{array}$ & $\begin{array}{c}\text { E } \\
(\text { SBP 10\%) }\end{array}$ & $\begin{array}{c}\text { F } \\
(2.6 \% \text { chitosan })\end{array}$ \\
\hline Total lipids (Tl) & $237.80 \pm 5.72^{a}$ & $267.20 \pm 3.27^{b}$ & $235.20 \pm 4.49^{\mathrm{a}}$ & $236.60 \pm 1.52^{\mathrm{a}}$ & $231.60 \pm 3.21^{\mathrm{a}}$ & $233.20 \pm 2.95^{\mathrm{a}}$ & $232.00 \pm 2.35^{\mathrm{a}}$ & $238.57 \pm 5.47^{\mathrm{a}}$ \\
\hline Triglyceride (TG) & $96.38 \pm 1.10^{\mathrm{a}}$ & $108.03 \pm 1.97^{b}$ & $92.33 \pm 1.85^{\mathrm{a}}$ & $95.98 \pm 3.35^{\mathrm{a}}$ & $95.22 \pm 3.11^{\mathrm{a}}$ & $94.44 \pm 3.76^{\mathrm{a}}$ & $96.66 \pm 3.48^{\mathrm{a}}$ & $94.87 \pm 3.15^{\mathrm{a}}$ \\
\hline Total Cholesterol (TC) & $127.77 \pm 1.53^{b}$ & $140.88 \pm 4.09^{\mathrm{c}}$ & $123.97 \pm 1.57 \mathrm{ab}$ & $122.31 \pm 1.23^{\mathrm{a}}$ & $126.34 \pm 3.09^{a b}$ & $128.17 \pm 2.20 \mathrm{~b}$ & $125.05 \pm 3.03 \mathrm{ab}$ & $126.16 \pm 3.27 \mathrm{ab}$ \\
\hline HDL-C & $38.20 \pm 1.79^{b}$ & $17.20 \pm 1.30^{\mathrm{a}}$ & $36.80 \pm 1.64 \mathrm{~b}$ & $36.20 \pm 3.70^{b}$ & $35.40 \pm 3.05^{b}$ & $37.00 \pm 2.55^{b}$ & $37.00 \pm 1.58 \mathrm{~b}$ & $35.71 \pm 2.54 \mathrm{~b}$ \\
\hline LDL-C & $70.29 \pm 0.91^{\mathrm{a}}$ & $102.08 \pm 5.43 \mathrm{~b}$ & $68.70 \pm 2.51^{\mathrm{a}}$ & $66.92 \pm 3.27^{\mathrm{a}}$ & $71.89 \pm 6.41^{\mathrm{a}}$ & $72.28 \pm 4.16^{\mathrm{a}}$ & $68.72 \pm 1.89^{\mathrm{a}}$ & $71.48 \pm 5.11^{\mathrm{a}}$ \\
\hline VLDL-C & $21.61 \pm 0.39^{b}$ & $21.61 \pm 0.39^{b}$ & $18.47 \pm 0.37^{\mathrm{a}}$ & $19.20 \pm 0.67 \mathrm{a}$ & $19.04 \pm 0.62^{\mathrm{a}}$ & $18.89 \pm 0.75^{\mathrm{a}}$ & $19.33 \pm 0.70^{\mathrm{a}}$ & $18.97 \pm 0.63^{\mathrm{a}}$ \\
\hline ClLDL & $1.81 \pm 0.05^{b}$ & $1.38 \pm 0.03^{\mathrm{a}}$ & $1.80 \pm 0.09^{b}$ & $1.83 \pm 0.09 \mathrm{~b}$ & $1.76 \pm 0.12^{b}$ & $1.77 \pm 0.08 \mathrm{~b}$ & $1.82 \pm 0.02 b$ & $1.77 \pm 0.09 b$ \\
\hline LDL\HDL & $1.84 \pm 0.10^{\mathrm{a}}$ & $5.95 \pm 0.70 \mathrm{~b}$ & $1.87 \pm 0.2^{\mathrm{a}}$ & $1.85 \pm 0.30^{\mathrm{a}}$ & $2.03 \pm 0.4^{\mathrm{a}}$ & $1.95 \pm 0.20^{\mathrm{a}}$ & $1.86 \pm 0.10^{\mathrm{a}}$ & $2.00 \pm 0.20^{\mathrm{a}}$ \\
\hline
\end{tabular}


Table 6. Means of serum biochemical parameters, liver and antioxidant enzymes activities in obese rats fed with artichoke by-product (ASP), shrimp by-product (SBP), inulin and chitosan.

\begin{tabular}{|c|c|c|c|c|c|c|c|c|}
\hline \multirow[b]{2}{*}{ Parameters } & \multicolumn{8}{|c|}{ Experimental groups } \\
\hline & $\begin{array}{c}\text { CG } \\
\text { Control diet }\end{array}$ & $\begin{array}{c}\text { PC } \\
\text { (HFD diet) }\end{array}$ & $\begin{array}{c}\text { A } \\
(\text { ASP 5\%) }\end{array}$ & $\begin{array}{c}\text { B } \\
(\text { ASP } 10 \%)\end{array}$ & $\begin{array}{c}C \\
\text { (7.7\% inulin) }\end{array}$ & $\begin{array}{c}\text { D } \\
(\text { SBP 5\%) }\end{array}$ & $\begin{array}{c}E \\
(\text { SBP 10\%) }\end{array}$ & $\begin{array}{c}\text { F } \\
(2.6 \% \\
\text { chitosan) }\end{array}$ \\
\hline Glucose (mg/dl) & $109.90 \pm 1.63^{\mathrm{a}}$ & $122.6 \pm 4.55^{b}$ & $110.50 \pm 1.7^{\mathrm{a}}$ & $111.90 \pm 1.66^{\mathrm{a}}$ & $110.10 \pm 0.97^{\mathrm{a}}$ & $113.5 \pm 0.62^{a}$ & $112.00 \pm 1.75^{\mathrm{a}}$ & $111.0 \pm 0.87^{\mathrm{a}}$ \\
\hline Total protein $(\mathrm{mg} / \mathrm{dl})$ & $6.15 \pm 0.17^{\mathrm{a}}$ & $7.69 \pm 0.28^{b}$ & $6.29 \pm 0.12^{\mathrm{a}}$ & $6.52 \pm 0.39^{a}$ & $6.31 \pm 0.19^{\mathrm{a}}$ & $6.65 \pm 0.10^{a}$ & $6.23 \pm 0.23^{\mathrm{a}}$ & $6.57 \pm 0.37^{\mathrm{a}}$ \\
\hline $\operatorname{Albumin}(\mathrm{mg} / \mathrm{dl})$ & $3.54 \pm 0.18^{a}$ & $4.10 \pm 0.21^{b}$ & $3.64 \pm 0.05^{\mathrm{a}}$ & $3.66 \pm 0.05^{\mathrm{a}}$ & $3.57 \pm 0.04^{\mathrm{a}}$ & $3.68 \pm 0.06^{\mathrm{a}}$ & $3.48 \pm 0.08^{\mathrm{a}}$ & $3.70 \pm 0.07 \mathrm{a}$ \\
\hline \multirow[t]{2}{*}{ Globulin (mg/dl) } & $2.61 \pm 0.09^{\mathrm{a}}$ & $3.59 \pm 0.14^{b}$ & $2.65 \pm 0.07^{\mathrm{a}}$ & $2.86 \pm 0.40^{\mathrm{a}}$ & $2.74 \pm 0.17^{\mathrm{a}}$ & $2.97 \pm 0.06^{\mathrm{a}}$ & $2.75 \pm 0.17^{\mathrm{a}}$ & $2.87 \pm 0.36^{\mathrm{a}}$ \\
\hline & \multicolumn{3}{|c|}{ Antioxidant enzyme } & & & & & \\
\hline CAT (U/L) & $359.20 \pm 5.67^{c}$ & $319.8 \pm 4.60^{\mathrm{a}}$ & $348.4 \pm 7.02 \mathrm{bc}$ & $344.6 \pm 4.83^{b}$ & $349.6 \pm 5.50 \mathrm{bc}$ & $354.6 \pm 8.08^{\mathrm{bc}}$ & $343.6 \pm 4.28^{b}$ & $358.6 \pm 5.5 \mathrm{c}$ \\
\hline GSH-Px (U/l) & $352.4 \pm 6.31^{\mathrm{b}}$ & $324.2 \pm 3.27^{\mathrm{a}}$ & $348.0 \pm 5.70^{b}$ & $345.0 \pm 7.07 \mathrm{~b}$ & $349.4 \pm 9.18^{b}$ & $348.4 \pm 7.44^{b}$ & $345.2 \pm 10.51^{\mathrm{b}}$ & $343.6 \pm 10.44^{b}$ \\
\hline \multirow[t]{2}{*}{$\mathrm{SOD}(\mathrm{U} / \mathrm{l})$} & $162.00 \pm 3.58^{\mathrm{b}}$ & $125.0 \pm 4.36^{\mathrm{a}}$ & $158.2 \pm 6.57^{b}$ & $159.0 \pm 5.48^{\mathrm{b}}$ & $160.2 \pm 3.96^{\mathrm{b}}$ & $158.8 \pm 7.79^{\mathrm{b}}$ & $156.6 \pm 10.60^{\mathrm{b}}$ & $159.8 \pm 7.69^{b}$ \\
\hline & \multicolumn{2}{|c|}{ Liver enzymes } & & & & & & \\
\hline AST (U/L) & $85.57 \pm 3.82^{\mathrm{a}}$ & $96.08 \pm 5.6^{\mathrm{b}}$ & $84.93 \pm 5.53^{\mathrm{a}}$ & $83.97 \pm 4.1^{\mathrm{a}}$ & $84.77 \pm 1.88^{\text {a }}$ & $86.13 \pm 2.02^{\mathrm{a}}$ & $84.72 \pm 2.47^{\mathrm{a}}$ & $85.82 \pm 4.55^{\mathrm{a}}$ \\
\hline ALT (U/L) & $84.73 \pm 5.8^{a}$ & $95.36 \pm 2.03^{b}$ & $78.69 \pm 1.14^{\mathrm{a}}$ & $81.45 \pm 1.22^{\mathrm{a}}$ & $82.45 \pm 1.86^{\mathrm{a}}$ & $81.57 \pm 5.55^{\mathrm{a}}$ & $80.33 \pm 2.16^{\mathrm{a}}$ & $78.66 \pm 3.68^{a}$ \\
\hline AlP (U/mg protein) & $83.59 \pm 2.83^{\mathrm{a}}$ & $96.70 \pm 4.54^{b}$ & $84.33 \pm 3.69^{a}$ & $83.63 \pm 4.10^{\mathrm{a}}$ & $80.53 \pm 1.84^{\mathrm{a}}$ & $85.91 \pm 2.02^{\mathrm{a}}$ & $82.18 \pm 1.79^{a}$ & $83.45 \pm 1.29^{\mathrm{a}}$ \\
\hline \multirow[t]{2}{*}{$\mathrm{ACP}(\mathrm{U} / \mathrm{L})$} & $15.02 \pm 0.89^{a}$ & $16.10 \pm 0.53^{b}$ & $14.73 \pm 0.38^{a}$ & $14.93 \pm 0.15^{\mathrm{a}}$ & $14.43 \pm 0.47^{\mathrm{a}}$ & $14.23 \pm 0.42^{\mathrm{a}}$ & $14.87 \pm 0.15^{\mathrm{a}}$ & $14.53 \pm 0.40^{\mathrm{a}}$ \\
\hline & \multicolumn{3}{|c|}{ Kidney functions } & & & & & \\
\hline Urea (mg/dl) & $52.51 \pm 1.70^{\mathrm{b}}$ & $57.89 \pm 3.36^{\mathrm{c}}$ & $42.20 \pm 0.64^{\mathrm{a}}$ & $41.41 \pm 1.96^{\mathrm{a}}$ & $43.91 \pm 2.22^{\mathrm{b}}$ & $42.72 \pm 0.72^{\mathrm{a}}$ & $43.12 \pm 4.33^{\mathrm{a}}$ & $42.89 \pm 3.38^{\mathrm{a}}$ \\
\hline Creatinine (mg/dl) & $1.55 \pm 0.02^{b}$ & $1.72 \pm 0.03^{\mathrm{c}}$ & $1.40 \pm 0.01^{\mathrm{a}}$ & $1.46 \pm 0.04^{\mathrm{a}}$ & $1.42 \pm 0.02^{\mathrm{a}}$ & $1.40 \pm 0.04^{\mathrm{a}}$ & $1.44 \pm 0.03^{\mathrm{a}}$ & $1.45 \pm 0.04^{\mathrm{a}}$ \\
\hline Bilirubin (mg/dl) & $1.46 \pm 0.04^{b}$ & $1.69 \pm 0.05^{\mathrm{c}}$ & $1.36 \pm 0.11^{\mathrm{a}}$ & $1.34 \pm 0.03^{\mathrm{a}}$ & $1.33 \pm 0.03^{\mathrm{a}}$ & $1.38 \pm 0.03^{\mathrm{a}}$ & $1.33 \pm 0.02^{\mathrm{a}}$ & $1.38 \pm 0.05^{\mathrm{a}}$ \\
\hline
\end{tabular}

Results are expressed as mean $\pm \mathrm{SD}$; Means with different superscript letters in the same row imply significant differences at $\mathrm{P} \leq 0.05$. 
In the same respect Table (6) showed, that the HFD group had significant increased in serum levels of total protein, albumin, and globulin by 25.04, 15.82 and $37.62 \%$ respectively when compared to the negative control group. These results are in agreement with Zhong et al. (2007), who found that administration of dietary fibers, i.e., sugar cane fiber and cellulose decreased glucose in serum rats. The dietary fiber as a prebiotics' stimulate the growth of beneficial bacteria in intestinal microbiota to produce SCFAs which had physiological benefits such as decreased the insulin response and glucose uptake; induce lower blood lipid levels; enhancement of mineral bioavailability (Rawi et al., 2020).

\section{Liver enzymes activities}

The results in Table (6) showed that the effect of different by-product on serum liver enzymes AST, ALT in obese rats. In the positive group, there were highly significant elevation in ALT, AST and ALP enzymes activity as compared with the other group. Administration of ASP, SBP, inulin at dosage $7.7 \mathrm{~g} / \mathrm{kg}$ bw and chitosan at dosage $2.6 \mathrm{~g} / \mathrm{kg}$ bw for 8 weeks to rats fed high fat showed remarkably amelioration the reduction in ALT, AST and ALP enzymes activity compared with the positive group. It was clear from Table (6) that administration of ASP at dose 5\% to rats showed significantly decrement by $17.48 \%$ in serum ALT enzyme when compared to the positive group and no significant reduction as compared to the negative group. In contrast, there was a significant decrement in serum ALP enzyme by $34.08 \%$ in rats given ASP at dose $10 \%$ when compared to the negative control group. Inulin at dosage $7.7 \mathrm{~g} \mathrm{~kg}$ bw caused significant decrement in the level of AST, ALP and AST enzyme when compared to the control group. Hepatocellular damage is identified by ALT and AST, where Cirrhosis, chronic hepatitis, alcoholic hepatitis, acute viral hepatitis, and toxic ischemic injury are all known to cause an increase in these aminotransferases (Yap and Aw. 2010).

\section{Activity of antioxidant enzymes}

As shown in Table (6), the results revealed that administration of ASP 5\%, ASP 10\%, inulin, SBP 5\%, SBP $10 \%$, and chitosan to fed obese rats significantly elevated and improvement in catalase (CAT) levels, glutathione peroxidase (GSH-Px), and superoxide dismutase (SOD) compared to the positive group after 8 weeks. It could be saw that the (SOD) levels were increased by $26.56,27.2,28.16,27.04,25.28$ and 27.84 $\%$ in for group A, B, C, D, E and F respectively as compared to the (SOD) level of the positive group.

These results were in agreement with $\mathrm{Wu}$ and Chen. (2011), who found that inulin enhanced the antioxidative defense systems by upregulating the gene expressions of glutathione peroxidase and catalase in the colonic mucosa and superoxide dismutase and catalase in the liver. Furthermore, promoted antioxidative status in the blood by elevating the R-tocopherol level. Inulin was well-fermented in rats and increased the concentration and daily excretion of fecal SCFAs, especially acetate and butyrate. These results suggest that in vivo utilization of inulin stimulated both local and systemic antioxidative defense systems in rats. Sia (2017) reported that chitosan $0.18 \mathrm{~g} /$ day) elevated TSOD and G3SH-PX concentrations in treatment group compared with normal group. More importantly, this study found that chitosan group performed the most efficiently in suppressing oxidative stress by elevating GSH-PX levels.

\section{kidney function}

As seen from the data in Table (6), the mean serum urea, and bilirubin values were not different in serum of rats' groups given all doses of ASP and SBP, while there were significant decrement in those treated groups compared to the positive control group. In the control group, this reduction was associated with decrement in kidney relative weight. Rats fed on inulin showed insignificantly reduction in serum urea, while it showed significantly decrement in creatinine and bilirubin when compared to the normal diet group. However, the creatinine values were higher in serum of HFD control group than the other treated group. These results are in agreement with Jiang et al. (2019) who showed that there was a significant reduction in serum creatinine in obesity rats treated with chitosan extract. The filtering ability of the kidneys declines as the disease progresses, resulting in the loss of essential blood proteins in the urine. The kidneys lost their ability to remove waste products like creatinine and urea, which could be tested in the blood to see how much kidney disease had progressed (Swaminathan 2004).

\section{CONCLUSION}

From our data we can concluded that the diet containing artichoke stem by-products (ASP), shrimp by-products (SBP) and either inulin as soluble fiber or chitin asinsoluble fiber decreased food intake and hence reduction weight gain, improved blood glucose level, reduced lipid levels of obese rat when compared to high fat diet rats. However, these food processing by- products can be used in the nutraceutical formulation of functional food products and a good source of natural dietary fiber to enhances the nutritional quality for prevention of diseases like obesity, and its associated health risks.

\section{REFERENCES}

A.O.A.C. 2000. Official Methods of Analysis. Association of Official Analytical Chemists, Gailhersburg, Maryland. USA. 
Abouzeed, A. S., E. O.Shaltout, S. M.Ibrahimm, R. S. Attia. and A. M.Aboul-yazeed. 2015. Production and evaluation of some bioactive compounds extracted from squilla (Oratosquilla massavensis) shells. American J. of Life Sci. 3(6-1): 38-44.

Allioua, M., D.Rabah, Y. M.Moustafa, B.Semir, G.Suheil, D.Harek, M.

B.Boumediene and B. Slimane. 2015. Dietary fat intake, micronutritient and obesity among adolescent in Tlemcen (western Algeria). Food and Nutrition Sci. 6: 860-868.

Anderson, W. J. and J. T. Hanna. 1999. Impact of nondigestible carbohydrates on serum lipoproteins and risk for cardiovascular disease. American Society for Nutritional Sci.129:1457-1466.

Attia, R. S., M. E.Nasser and I. M.Mona. 2016. Evaluation of artichoke bracts as a potential source of bioactive compounds, bio-ethanol production and livestock feeding. Alexandria J. of Food Sci. and Technology.13: 51-62.

Bergmeyer, H. U., P. Scheibe and W. W.Wahlefeld. 1978. Optimization of methods for aspartate amino transferase and alanine amino transferase. Clin. Chem. 24 (1): 58-73.

Ble-Castillo, L. J., A. M.Aparicio-Trapala, E. I. Juárez-Rojop, E. J.Torres-Lopez, D. M.Jose, H.Aguilar-Mariscal, V. C.Olvera-Hernández, L. Palma-Cordova and J. DiazZagoya. 2012. Differential effects of high-carbohydrate and high-fat diet composition on metabolic control and insulin resistance in normal rats. International $\mathrm{J}$. of Environmental Research and Public Health. 9:1663-1676.

Bonsu, K. A. N. and S.Johnson. 2012. Effects of inulin fiber supplementation on serum glucose and lipid concentration in patients with type 2 diabetes. Int. J. Diabetes and Metab. 21:80-86.

Causey, L. J., M. J.Feirtag, D. D.Gahaher, C. B. Tuqland and L. J. Slavin. 2000. Effects of dietary inulin on serum lipids, blood glucose and the gastrointestinal environment in hypercholesterolemic men. Nutrition Research. 20(2): 191-201.

Chapman, D. G., R. Castillo and J. A. Campbell. 1959. Evaluation of protein in foods: 1-A method for the determination of protein efficiency ratio. Canadian J. of Biochemistry and Physiology. 37(5): 679-86.

Cherbut, C., E.Albina, M.Champ, J. L. Doublier and G.Lecannu. 1990. Action of Guar Gums on the Viscosity of Digestive Contents and on the Gastrointestinal Motor Function in Pigs. Digestion. 46(4): 205-213.

Chiu, C., T.Yen, S. Liu and M.Chiang. 2020. Comparative effects and mechanisms of chitosan and its derivatives on hypercholesterolemia in high-fat diet-fed rats. International J. Molecular Sci. 21(1): 92-102.

Claus, T., S. A.Maruyama, S.V.Palombini, P. F.Montanher, E. G.Bonafe, O. D.

O. S.Junior and J.V. Visentainer. 2015. Chemical characterization and use of artichoke parts for protection from oxidative stress in canola oil. LWT - Food Sci. and Technology. 61: 346-351.

Collins, J. G. 2008. Postapproval Monitoring and the Institutional Animal Care and Use Committee (IACUC). ILAR J. 49(4):388-392.
Dai, Z., Y.Zhang, N.Lu, T.David, A.Felson, P. K. Douglas and S.Shivani. 2018. Association between dietary fiber intake and bone loss in the framingham offspring study. J. Bone Miner Res. 33(2): 241-249.

Delzenne, M. N. and N. N. Kok. 1999. Biochemical basis of oligofructose-induced hypolipidemia in animal models. American Society for Nutritional Sci. 129 (7): 14671470 .

Doumas, B. T., H. G.Biggs, R. L. Arends and P.V. C. Pinto. 1971. Albumin standard and the measurement of serum albumin with bromocresol green. Clin. Chem. Acta. 31(1): 87- 95 .

Eman, A. M., M. A. M.Zeitoun, A. A. Wafaa and M. O. Hanem. 2018. Evaluation of Globle artickoke by-product for enhancing functional properties of some foods. J. Adv. Res. (Fac.Agric.Saba Basha). 23(1):112-115.

Fossati, P. and L.Prencipe. 1982. Serum triglycerides determined colorimetrically with an enzyme that produces hydrogen peroxide. Clinical Chemistry. 28(10): $2077-$ 2080.

Fernstrand, A. M., D.Bury, J.Garssen and J. C.Verster. 2017. Dietary intake of fibers: differential effects in men and women on perceived general health and immune functioning. Food and Nutrition Research. 61(1): 1297053.

Franco-Robles, E. and M. G. López. 2015. Implication of fructans in health: immunomodulatory and antioxidant mechanisms. The Scientific World J. 2015:1- 15.

Fratianni, F., M.Tucci, M. D.Palma, R. Pepe and F. Nazzaro. 2007. Polyphenolic composition in different parts of some cultivars of globe artichoke (Cynara cardunculusL. var. scolymus (L.) Fiori). Food Chemistry.104(3): 1282-1286.

Friedewald, W. T., R. I. Levy and D.S. Fredrickson. 1972. Estimation of the concentration of low-density lipoprotein cholesterol in plasma, without use of the preparative ultracentrifuge. Clinical Chemistry. 18(6): 499-502.

GIA. 2005. Chitin \& chitosan. A Global Strategy Business Report. Global Industry Analyst, INC. July.

Gebhardt, R. 1998. Inhibition of cholesterol biosynthesis in primary cultured rat hepatocytes by artichoke (Cynara scolymus L.) extracts. The J. of Pharmacology and Experimental Therapeutics. 286(3): 1122- 1128.

Goering, H. K. and P. J. Van Soest. 1970. Forage Fiber Analyses: Apparatus, Reagents, Procedures and Some Application. Agr. Handb. ARS, Washington, DC, USA, PP:379.

Grundy, M. M. L., C. H.Edwards, A. R.Mackie, M. J.Gidley, P. J.Butterworth and P. R. Ellis. 2016. Re-evaluation of the mechanisms of dietary fibre and implications for macronutrient bioaccessibility, digestion and postprandial metabolism. British J. of Nutrition. 116(05):816-833.

Henry, T. J. 1974. Creatinine measurements with colorimetric method. In: Clinical chemical principles and techniques (2nd edition). New York: Harper and Row Publishers.

Hopping, B. N., E.Erber, A.Grandinetti, S. Y.Park, L. N. Kolonel and G. Maskarinec. 2010. Dietary fiber, magnesium, and glycemic load alter risk of type 2 diabetes in a multiethnic cohort in Hawaii. J. Nutr. 140: 68-74. 
Huang, L., J. Chen, P.Cao, H.Pan, C.Ding, T.Xiao, P.Zhang, J. Guo and Z.Su. 2015. Anti-obese effect of glucosamine and chitosan oligosaccharide in high-fat diet-induced obese rats. Marine Drugs.13: 2732-2756.

Jiang, T., X.Xing, L.Zhang, Z.Liu, J.Zhao and X. Liu. 2019. Chitosan oligosaccharides show protective effects in coronary heart disease by improving antioxidant capacity via the Increase in intestinal probiotics. Oxidative Medicine and Cellular Longevity. 1- 11.

Johnston, D. J. 2003. Ontogenetic changes in digestive enzyme activity of the spiny lobster, Jasus edwardsii (Decapoda; Palinuridae). Marine Biology. 143(6): 10711082.

Kakkar, P., B.Das and P. N. Viswanathan. 1984. A modified spectrophotometric assay of superoxide dismutase. Indian J Biochem Biophys. 21(2):130-132.

Khambualai, O., K.Yamauchi, S. Tangtaweewipat and B. Cheva-Isarakul. 2008. Effects of Dietary Chitosan Diets on Growth Performance in Broiler Chickens .The J. of Poultry Sci. 45:206-209.

Kind, P. R. N. and E. J. King. 1954. Estimation of plasma phosphatase by determination of hydrolysed phenol with amino-antipyrine. J. of Clinical Pathology. 7(4): 322-326. Küçükgergin. C., F. A.Aydın, G.Özdemirler-Erata, G.Mehmetçik, N. Koçak-Toker and M.Uysal. 2010. Effect of artichoke leaf extract on hepatic and cardiac oxidative stressin rats fed on high cholesterol diet. Biol Trace Elem Res. 135: 264-274.

Lane-Peter, W. A. and A. E. Pearson. 1971. Dietary Requirements. In: The Laboratory Animal Principles and Practice, Lane-Peter, W. A. and A. E. Pearson (Eds.). Academic Press, London, New York. pp: 142.

Larrosa, S., V.Luque, V.Grote, R.Closa-Monasterolo, N.Ferré, B.Koletzko, E.Verduci, D.Gruszfeld, A.Xhonneux and J.Escribano. 2021. Fibre intake is associated with cardiovascular health in European children. Nutrients. 13(1): 12-25.

Lertsutthiwong, P., N. C.How, S. Chandrkrachang and F. S. Willem. 2002. Effect of chemical treatment on the characteristics of shrimp chitosan. J. of Metals, Materials and Minerals. 12 (1): 11-18.

Lowry, O. H., N. J.Rosebrough, A. L. Farr and R. J. Randall. 1951. Protein measurement with the folin phenol reagent. J. of Biological Chemistry. 193: 269-275.

Meneses, M., M. D.Meg'1as, J.Madrid, A.Mart'1nez-Teruel, F.Hern'andez and J. Oliva. 2007. Evaluation of the phytosanitary, fermentative and nutritive characteristics of the silage made from crude artichoke (Cynara scolymus L.) by-product feeding for ruminants. Small Rumin. Res. 70:292-296.

Mohanty, D., S.Misra, S. Mohapatra and P. S. Sahu. 2018. Prebiotics and synbiotics: Recent concepts in nutrition. Food Bioscience. 26:152-160.

Muñoz, I., C.Rodríguez, D.Gillet, B. M. Moerschbacher. 2018. Life cycle assessment of chitosan production in India and Europe. Int. J. Life Cycle Assess. 23:11511160.

Muzzarelli. A. A. R. and R. Rocchetti. 1985. Determination of the degree of acetylation of chitosans by first derivative ultraviolet spectrophotometry. Carbohydrate Polymers. 5(6): 461- 472 .
No, H. K. and S. P. Meyers. 1995. Preparation and characterization of chitin and chitosan-A Review. J. of Aquatic Food Product Technology. 4 (2): 27-52.

Ogungbemi, K., N. R.Ugbaja, F. F.Ilesanmi, O. A.Ilori, A. T.Odeniyi, M. B.Adeniyi, A. D. Balogun and S. S. Ajisafe. 2020. Effect of dietary chitosan on the feed efficiency and weight performance of high fat diet induced hyperlipidemia in male wistar rat. International $\mathrm{J}$. of Scientific Reports. 6(3):90-94.

Paglia, D. E. and W. N. Valentine. 1967. Studies on the quantitative and qualitative characterization of erythrocyte glutathione peroxidase. J. of Laboratory and Clinical Medicine. 70(1): 158-169.

Rawi, H. M., S.Zaman, F. K.Pa'ee, S. S. Leong and R. S. Sarbini. 2020. Prebiotics metabolism by gut-isolated probiotics. J Food Sci. Technol. 57(8): 2786-2799.

Reeves, P.G., F.H. Nielsen and G.C. Fahey. 1993. AIN-93 purified diets for laboratory rodents: final report of the American Institute of Nutrition ad hoc writing committee on the reformulation of the AIN-76A rodent diet. American Institute of Nutrition.123:1939- 1951.

Sadasivam, S. and A. Manickam. 1992. Biochemical Methods for Agricultural Sci.Wiley Eastern Ltd., New Delhi, pp. 199-201.

Salem, M. B., K. Ksouda, R.Dhouibi, C.Slim, M.Turki, S.Hammami, F.Ayedi, Z.Sahnoun, M. K.Zeghal and H.Affes. 2019. LC-MS/MS Analysis and Hepatoprotective Activity of Artichoke (Cynara scolymus L.) Leaves Extract against High Fat Diet-Induced Obesity in Rats BioMed Research International.

Salman, F. M., Y. A. A.El-Nomeary, A. A.Abedo, H. H.Abd El-Rahman, M.I. Mohamed and S. M. Ahmed. 2014. Utilization of artichoke (Cynara scolymus) by-products in sheep feeding. American-Eurasian J. of Agricultural \& Environmental Sci. 14: 624- 630.

Saura-Calixto, F., A.Garc'1a-Alonso, I.Go ni and L.Bravo. 2000. In vitro 595 determination of the indigestible fraction in foods: An alternative to dietary fiber analysis. J. Agric. Food Chem. 48:3342-3347.

Sharma, A., B. J. Jones and F. F.White. 2019. Recent advances in developing disease resistance in plants. F1000 Research. 8.1934.

Shoaib, M., S.Aamir, O.Mukama, R. Allah R,Husnain, R. S. Hafiz, S. Azam, A. Anum and N.Sobia. 2016. inulin: Properties, health benefits and food applications. Carbohydrate Polymers. 147:444 - 454.

Sia, X., P.Strappeb, B. Chris and Z.Zhou. 2017. Enhanced anti-obesity effects of complex of resistant starch and chitosan in high fat diet fed rats. Carbohydrate Polymers.157: 834- 841.

Sinha, A.K. 1972. Colorimetric assay of catalase. Anal Biochem. 47:389-394.

Siracusa, F., N.Schaltenberg, J. E.Villablanca, S.Huber and N.Gagliani. 2019. Dietary habits and intestinal immunity: From Food Intake to $\mathrm{CD}^{+} \mathrm{T}_{\mathrm{H}}$ cells. Frontiersin immunology. 9.

Soliman, G. A. 2019. Dietary fiber, atherosclerosis, and cardiovascular disease. Nutrients. 11(5): 1155. 
Sumiyoshi, M. and Y.Kimura. 2006. Low molecular weight chitosan inhibits obesity induced by feeding a high-fat diet long-term in mice. J. of Pharmacy and pharmacology. 58 (2): 201-207.

Swaminathan, S., K.Sud, N.Varma, H. S.Kohli, V.JHA, K. L.Gupta and V. Sakhuja. 2004. Reversal of pancytopenia following kidney transplantation in a patient of primary hyperoxaluria with bone marrow involvement. Nephrology. 9(6):422-425.

Tietz, N. W. 1976. Fundamentals of Clinical Chemistry. Saunders WB company, Philadelphia. PA. Pp: 243.

Tokatl1, K. and A.Demirdöven. 2017. Optimization of chitin and chitosan production from shrimp wastes and characterization. J. of Food Processing and Preservation. 42(2): 13494.

Trinder, P. 1969. Determination of glucose in blood using glucose oxidase with an alternative oxygen acceptor. Ann. Clin. Biochem. 6:24-27.

US Department of Agriculture (USDA), US Department of Health and Human Services. Dietary Guidelines for Americans. Washington, DC: USDA. 2005.

Van Waes, C., J.Baert, L.Carlier, E.Van Bockstaele. 1998. A rapid determination of the total sugar content and the average inulin chain length in roots of chicory (Cichorium intybus L). J Sci Food Agric. 76:107-110.

Vassault, A., D.Grafmeyer and C. Naudun. 1986. Protocole de validation de techniques (document B, stade 3). Ann Biol Clin. 44: 686-745.

Vergara-Valencia, N., E.Granados-Pérez, E.Agama-Acevedo, J.Tovar, J. Ruales and L. A. Bello-Pérez. 2007. Fibre concentrate from mango fruit: Characterization, associated antioxidant capacity and application as a bakery product ingredient. LWT - Food Sci. and Technology. 40(4): 722-729.
Warnick, G. R., R. H.Knopp, V. Fitzpatrick and L.Branson. 1990. Estimating low-density lipoprotein cholesterol by the Friedewald equation is adequate for classifying patients on the basis of nationally recommended cut points. Clin Chem. 36(1):15-19.

Whisner, C. M. and L.F. Castillo. 2018. Prebiotics, bone and mineral metabolism Calcif Tissue Int .102:443-479.

Wieland, H. and D.Seidel. 1983. A simple specific method for precipitation of low-density lipoproteins. J. of Lipid Research. 24(7):904-909.

Wu, W. T. and H. L. Chen. 2011. Konjac glucomannan and inulin systematically modulate antioxidant defense in rats fed a high-fat fiber-free diet. J. of Agricultural and Food Chemistry. 59 (17): 9194-9200.

Yadav, M., P.Goswami, K.Paritosh, M.Kumar, N. Pareek and V. Vivekanand. 2019. Seafood waste: a source for preparation of commercially employable chitin/chitosan materials Bioresour. Bioprocess. 6 (8):2-20.

Yap, C., T.C. Aw. 2010g. Liver Function Tests (LFTs). Proceedings Singapore. Healthcare. 19: 80-82.

Young, I. S. 2001. Measurement of total antioxidant capacity. J. of Clinical Pathology.54(5):339-339.

Zentralblatt fur Gesamte Experimental Medizin. 135:545-561. Zhong, Q., A.Zuberi, X. H.Zhang, J.Macgowan, J.Qin, Y. B.Xin, L.Son, W.Qinglin, L.Kun and T. C.William. 2007. Effects of dietary fibers on weight gain, carbohydrate metabolism and gastric ghrelin gene expression in high fat diet fed mice. Metabolism. 56(12): 1635-1642.

Zollner, N. and K.Kirsch. 1962. Determination of the total lipid concentration in serum.

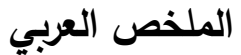

\section{تأثير تناول الوجبات المدعمة بمتبقيات عمليات التصنيع للخرشوف والجمبري على الفئران البدينة}

ناصر إبراهيم الصاوى أبو النجا، منى إبراهيم مسعود، أمل محمد عبد الرازق ، محد عماد ناصر، ،أماني رزق الجزار

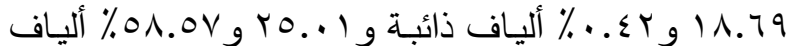

غير ذائبة في ASP و SBP منزوع الدهن على التوالي. كما

تميزت بارتفاع محتواها من الاينولين حيث ييلغ ب. 1 ا جم /

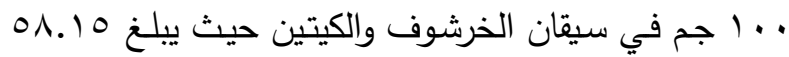

جم/ · • ا جم قشر جمبري. وتم دراسة التقييم البيولوجي على

مجموعـة تـم تغـيتها علي وجباتقياسـية (كنترول) ومقرانتها

بمجموعـة مـن الفُــران البدينــة، وتـم تقسـيمهم الـى سـبع

مجموعـات كالتـالي مجموعـة موجبـة (PC) ومجموعـات تـم

تغـذيتها بـ ASP و SBP بتركيـز 0 و ، ( ٪ وانيـولين بتركيـز

جم/كجم من الوجبة وكيتوزان بتركيز ج.V
تسـاهم الأغذيـة المدعمـة بالأليـاف الغذائيـة الوظليفيـة في

الوقايـة مـن بعـض الأمـراض مثثل الســنة وأمـراض القلـب

والأوعية الدمويـة ومرض السكري. لذا أجريت الدراسـة لتقدير

محتـوى الأليـاف الغذائيـة فـي متبقيـات عمليـات التصــيع

للخرشـوف (ASP) والجمبـري (SBP) وتقيـيم التـأثير الوقـائي

للوجبـة المدعمـة بتلـك المتبقيـات الغنيـة بالأليـاف الغذائيـة

الطبيعيـة على وزن الجسـ، صـورة الدم، المقاييس الكيميائية

الحيوية وأنشطة إنزيمات الكبد في الفئران البدينة. وقد أظهرت

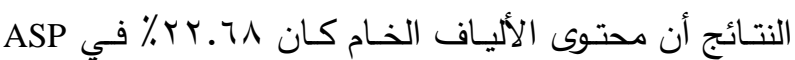

و وج.ب ا ٪ في SBP. وتتكـون الأليـاف الغذائيـة الكليـة مـن 
انخفــاض تركيــز الكوليســترول والجليســريدات الثلاثيـــة والليبوبروتينات منخفضة الكثافة، وانخفاض معنوي في تركيز

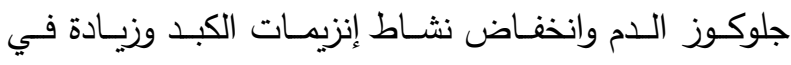
الانزيمـات المضـادة للأكســة مقارنـة بالمجموعـة الإيجابيـة. لـلك يمكن الاسـتفادة مـ ASP كمصـدر للإينـولين و وكBP

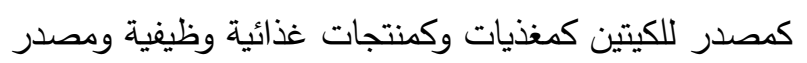

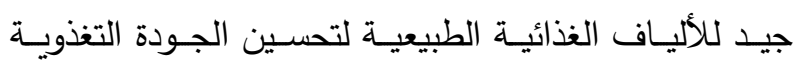
للوقايـة مـن الأمـراض كالسمنة ومـا يـرتبط بهـا مـن مخـاطر صحية. الكلمـات المفتاحيـة: الأليـاف الوظيفيـة، الألياف الغذائية الطبيعية، الاينولين، الكيتين، المغذيات. الوجبة لمدة ^ اسـابيع وقورنت بالمجموعـة الكنترول التي تم تغذيتها بالوجبة القياسية. وقد أوضحت النتائج حدوث تحسن

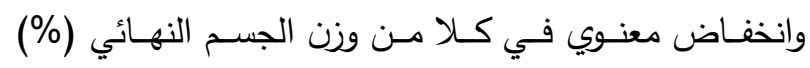
ومعدل الزيـادة في وزن الجسـ (\%) ومعـدل كفـاءة التغذيـة (FER)

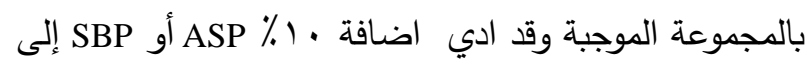

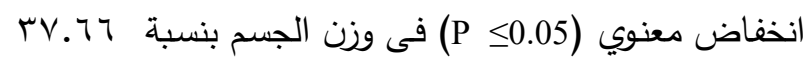

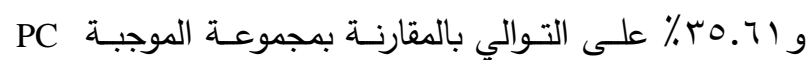

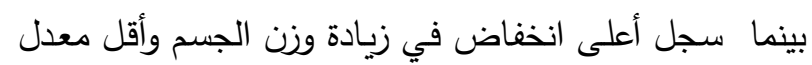
في FER في المجموعات التي تغذت على الشيتوزان. أدت تغذية الفئران البدينة على وجبة محتوية علي ASP و 